\title{
Penukaran Data Dalam Konteks GIS (Geographical Information System)
}

\author{
AZIZAH ABDUL MANAF DAN \\ GHAZALIE SULONG \\ Fakulti Sains Komputer Dan Sistem Maklumat \\ Universiti Teknologi Malaysia, \\ Jalan Semarak, 54100 \\ Kuala Lumpur.
}

\section{ABSTRAK}

Kertas kerja ini membincangkan kajian literatur mengenai proses awal yang perlu dititikberatkan dalam pembangunan suatu GIS (Geographical Information System). Dalam pembangunan sistem maklumat geografi (GIS), proses penukaran data (data conversion) merupakan proses awal yang perlu dilalui untuk mencapai kepada tahap pangkalan data geografi yang bermutu tinggi. Proses ini juga biasanya merupakan sebahagian terbesar daripada keseluruhan projek GIS dan secara tidak langsung kos untuk proses tersebut juga adalah yang paling tinggi iaitu dalam lingkungan $60 \%$. Dari segi terminologi pula, terdapat dua aspek proses penukaran dan di dalam kertas kerja ini salah satu aspek yang akan dibincangkan iaitu dari segi persediaan awal berkaitan dengan spesifikasi projek penukaran, spesifikasi data dan spesifikasi pentadbiran harus dilaksanakan sebelum proses penukaran (conversion) dapat dijalankan dengan lancar.

Setiap sistem AM/FM pula, memerlukan kepada satu dasar tanah yang tepat, terkini dan selaras dengan tempat data fasiliti dirujuk secara geografik. Dengan lain perkataan, tanpa dasar tanah, sesuatu sistem pemetaan tidak boleh dikatakan sebagai satu GIS. Beberapa teknik perolehan dasar tanah dibincangkan dengan serba ringkas untuk membolehkan perhatian ditumpukan kepada masalah penyediaan dan pembersihan data fasiliti yang akan dirujuk terhadap dasar tanah ini kelak. Pembersihan data fasiliti adalah amat perlu supaya data yang dimasukkan semasa proses penukaran berada dalam keadaan baik dan tidak mendatangkan masalah semasa penggunaan kelak. Ini juga dapat menjimatkan kos pengguna dalam jangka masa panjang. Mutu maklumat yang akan ditukar juga perlu diambilkira.

Katakunci: Peta, Pangkalan Data, Geografi. Digital, Pengimbas, Pendigit, Cerapan Lapangan, Perantaramuka, terpusat, Teragih, Skedul, Sistem Unjuran, Koordinat, AM/FM (Pemetaan Terotomat/ Fasiliti), Pendigit stereo, Fotogrametri, Imbasan, Raster, Pendigit Stereo, Ortofotografi, Pengurus Grafik, Pembaca Kad Optik, Perantaramuka, Fonetik, PERT/CPM (project Evaluation Revision Technique/ Critical Path Method)

\section{ABSTRACK}

This paper will discuss on a literature study on early stages in the development of a GIS (Geographical Information System). In the development of a GIS, data conversion is the initial process that one has to undergoe in order to achieve a geographic of high quality. This process often constitutes to more than half of the total of a GIS project and indirectly the cost for this process is usually around $60 \%$. In terms of terminology there are two aspects of data conversion in a GIS namely, conversion of analogue/manual geographic data to digital form which involves manual sources such as paper maps, drawings, digital form etc. and conversion from one GIS system to another GIS system of different format. In this paper only the first aspect will be discussed in depth regarding early preparations to be considered in the data conversion and this pertains to project specifications, data specification and administrative specifications.

Every GIS requires a current, uniformly accurate landbase to which the facilities data can be geographically referenced. In other words, a computerised mapping system is nota a true GIS if it is not referenced to land base. Techniques on land base acquisition is disscussed in brief to allow the author to express in detail problems concerning the importance of data preparation and purification before the final conversion takes place. Data preparation and purification is viable so as not to input 'garbage' and 'output' garbage as well. Quality control on data to be converted should aslo be taken into consideration. 
Keyword: Maps, Database, Geographic, Digital, Scanner, Field observation, Interface, Centralised, Distributed, Schedule, Projection System, Coordinate, AM/FM (Automated Mapping/Facility Management), Photogrammetry, Scanning, Stereodigitizing, Ortophotography, OCR (Optical Card Reader), Interface, Phonetic, PERT/CPM (Project Evaluation Revision Technique/Critical Path Method)

\section{PENGENALAN}

Komponen yang paling berharga dalam pembangunan suatu GIS bagi sesuatu organisasi yang mengendalikan fasiliti ialah proses penukaran data (Gambarajah 1). Masalah ini telah banyak diperbincangkan. Lihat [Henry, E.A, 1989], [Charles, H.D, 1990], [Karen, 1, 1990], dan [Sakashita.S, Yutaka.T , 1990]. Data fasiliti berada dalam berbagai bentuk iaitu (1) Peta-peta lukisan-lukisan dan lain dokumen sumber yang berkaitan dengan data yang berkedudukan (2) Bentuk digital dalam format tertentu yang perlu dikenalpasti (gambarajah 2). Daripada segi pengistilahan pula, penukaran data (data conversion) bagi suatu GIS/LIS dapat dibahagikan kepada 2 jenis iaitu:-

1. Penukaran data daripada satu sistem GIS kepada sistem GIS yang lain di mana banyak perkara yang perlu diambilkira iaitu dari segi format data, ujuran data dan rujukan data.

2. Penukaran data daripada sistem manual kepada bentuk digital.

Proses penukaran merupakan suatu proses yang terlibat dengan penukaran rekod insani yang sedia ada kepada pangkalan data pintar dan terujuk secara geografi. Kemampuan untuk menggunakan data digital yang sedia-ada dalam format tertentu sangat penting. Malangnya, terdapat banyak masalah yang perlu dihadapi sebelum dapat menggunakan data berkenaan. Untuk mengatasi masalah penukaran data berbentuk sedemikian, pengguna GIS perlu mengikuti beberapa siri langkah lojik dan peraturan-peraturan untuk menukar data peta digital yang sedia-ada. Jika set peraturan dan prosedur tertentu diikuti, maka penukaran data digital yang sedia-ada boleh menjimatkan kos. Walau bagaimanapun pada peringkat permulaan, kita akan melihat cara pemprosesan penukaran data yang terdapat pada kertas atau peta-peta. Sebelum proses penukaran tersebut dapat dilaksanakan dengan jayanya, beberapa proses tertentu perlu dilaksanakan.

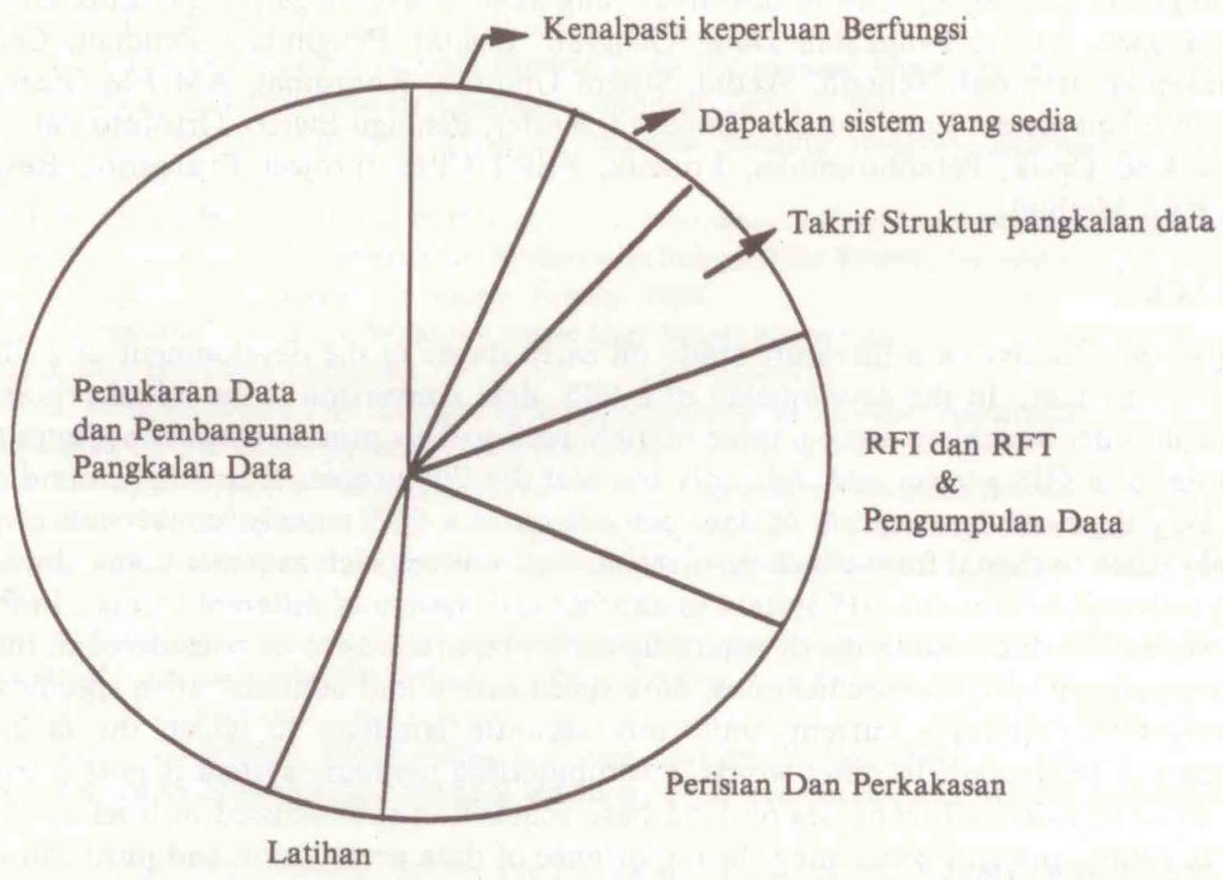

Gambarajah 1: Anggaran Pecahan Kos GIS (Lyons \& Sharma, 1990) 


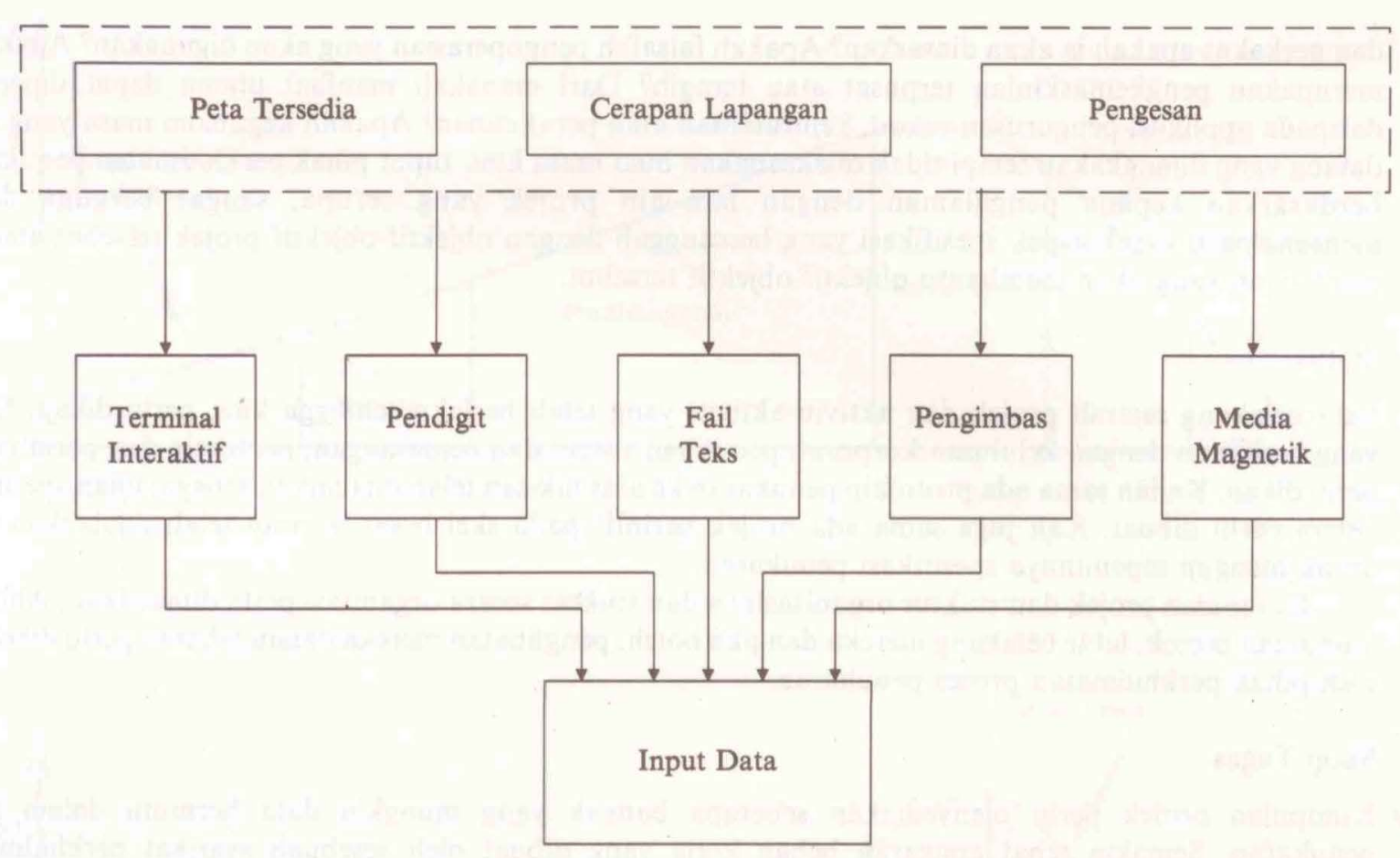

Gambarajah 2: Input data GIS (K.J.Lynos, Sharma, 1990)

\section{MEMBANGUNKAN SPESIFIKASI PENUKARAN (CONVERSION)}

Spesifikasi bagi proses penukaran biasanya merupakan asas untuk sesuatu organisasi menganggar tugas (dengan itu kosnya) untuk membina satu pangkalan data berkomputer, yang mengandungi data aritbut dan grafik untuk memenuhi keperluan operasional bagi tujuan menyelenggarakan perisian dan prosedur yang sedang dilaksanakan oleh pelanggan [Blunt, R.A, 1989]. Sebelum daripada ini, ada yang menakrifkan spesifikasi proses penukaran hanya sebagai spesifikadi grafik dan skima pengkalan data yang menerangkan format data yang akan disampaikan atau dihasilkan.

Topik-topik yang akan dibincang di dalam spesifikasi bagi proses penukaran ini boleh dirumuskan kepada 3 tajuk utama seperti di bawah [Blunt, R.A, 1989] :-

1. Spesifikasi projek iaitu status semasa, skop, matlamat dan skedul projek GIS

2. Spesifikasi data iaitu takrifan kedua-dua data sumber dan hasil yang akan dikeluarkan.

3. Spesifikasi pentadbiran iaitu spesifikasi yang akan menakrif keperluan perantaramuka projek.

\section{Spesifikasi Projek}

Dalam bahagian ini, organisasi fasiliti membekalkan maklumat mengenai GIS yang telah dirancang, justifikasinya dan bagaimana ia akan berfungsi dalam suatu organisasi. Latar belakang projek dan status semasa dapat membantu pihak perkhidmatan penukaran memahami darjah kesempurnaan perlaksanaan proses dan mengenalpasti aktiviti-aktiviti pembangunan yang tidak akan berubah. Skop tugas dan perancang tersebut akan menakrif berbagai parameter yang berupaya untuk membantu dalam menentukan perbelanjaan penukaran.

\section{Objektif}

Objektif sistem GIS perlu dijelaskan. Bagaimanakah ia dilaksanakan dalam organisasi tersebut? Perisian 
dan perkakas apakah ia akan diasaskan? Apakah falsafah pengoperasian yang akan digunakan? Apakah ia merupakan pengkemaskinian terpusat atau teragih? Dari manakah manfaat utama dapat diperolehi daripada applikasi pengurusan rekod, kejuruteraan atau perakaunan? Apakah kegunaan masa yang akan datang yang dijangkakan tetapi tidak dilaksanakan buat masa kini. Input pihak perkhidmatan penukaran, berdasarkan kepada pengalaman dengan lain-lain projek yang serupa, sangat berguna dalam mengenalpasti aspek-aspek spesifikasi yang bercanggah dengan objektif-objektif projek tersebut ataupun pembaikan yang akan membantu objektif-objektif tersebut.

Status

Latarbelakang sejarah projek dan aktiviti-aktiviti yang telah berlaku sehingga kini, perlu dikaji. Status yang berkaitan dengan kelulusan korporat, pemilihan sistem dan pemasangan, prototaip dan perintis juga perlu dikaji. Kajian sama ada prototaip penukaran ke atas lukisan telah dijalankan sebagai ujian spesifikasi sistem perlu dibuat. Kaji juga sama ada projek perintis pada skel besar-besaran telah dijalankan demi untuk menguji sepenuhnya spesifikasi penukaran.

Kumpulan projek dan stuktur organisasinya dan stuktur secara organisasi perlu ditakrifkan. Ahli-ahli kumpulan projek, latar belakang mereka dan jika boleh, penglibatan mereka dalam jabatan perlu diketahui oleh pihak perkhidmatan proses penukaran.

\section{Skop Tugas}

Kumpulan projek perlu menyediakan seberapa banyak yang mungkin data bermutu dalam tugas penukaran. Semakin tepat anggaran beban kerja yang dibuat oleh sesebuah syarikat perkhidmatan, semakin kurang jangkaan atau ketidakpastian yang akan ditemui. Bilangan bagi setiap jenis rekod insani yang wujud yang boleh dibekalkan kepada syarikat perkhidmatan juga perlu dikenalpasti. Luas kawasan geografi yang terlibat dan ciri-ciri kawasan tersebut perlu diketahui. Jika ia mengandungi kawasan bandar atau luar bandar, apakah kadar pembangunan setiap satu? Peta-peta keseluruhan boleh dibekalkan sebagai bahagian daripada pekej penetapan harga penukaran. Berapa ramai pelanggan yang menggunakan rangkaian tersebut dan adalah lebih baik jika mengetahui bagaimana mereka akan disubpecahkan iaitu kepada kategori Perniagaan/Pendudukan atau Bandar/Luar Bandar.

Cara bagaimana projek-projek disubpecahkan kepada pekej tugas atau subprojek serta bilangan subprojek yang akan diadakan perlu ditentukan. Sebagai contoh, dalam penukaran rekod telefon, ia merupakan pusat bagi setiap talian atau 'exchange' dalam penghantaraan elektrik ia mungkin merupakan litar atau substation, dalam sistem lain ia mungkin berbentuk peruasan geografik. Pertanyaan-pertanyaan mungkin timbul mengenai cara bagaimana hasil bagi tugas yang selesai boleh dimasukkan ke dalam pengkalan data utama di tempat pelanggan. Prosedur tertentu mesti membolehkan penyelenggaraan terus kepada data yang terhasil dan untuk menambah hasil-hasil kepada data tersebut. Teknik yang dicadangkan perlu dispesifikasikan dalam spesifikasi tersebut. Adakah projek perintis akan menjadi aktiviti permulaan dalam proses penukaran berkenaan?

Projek perintis mungkin diperlukan untuk membolehkan ulasan terakhir spesifikasi dibuat, sebelum penukaran pada skel sepenuhnya dimulakan. Ia mungkin juga ditentukan untuk mengesahkan pemahaman pihak perkhidmatan penukaran mengenai spesifikasi tersebut. Biasanya, tanpa mengira pengistilahan pelanggan, suatu syarikat perkhidmatan melihat proses penukaran awal sebagai perintis dan akan menentukan satu perancangan yang cukup luas membolehkan lebih pembaikan kepada prosedur dan spesifikasi tersebut. Statistik lengkap mengenai rangkaian kemudahan perlu disediakan. Jenis-jenis kemudahan dan kuantiti setiap jenis iaitu kabel/konduktor/paip, panjang paip, panjang jalan, panjang parit dan lain-lain perlu diketahui. Bilangan anggaran rekod terkomputer, fail-fail, saiz pangkalan data perlu disediakan jika mungkin.

Dalam banyak lapangan, hasil-hasil prototaip dan projek perintis membenarkan penubuhan suatu. kadar antara rekod lama dan baru. Isipadu kemaskinian akan dibina semasa proses penukaran, dan kaedah yang dicadangkan untuk mengendalikan 'backlog' apabila penukaran telah selesai adalah dikenalpasti. Ini merupakan isu ketara yang telah mengakibatkan halangan aliran tugas penukaran sedangkan kumpulan projek sendiri mempunyai masalah dalam 'backlog' penyelenggaraan. 


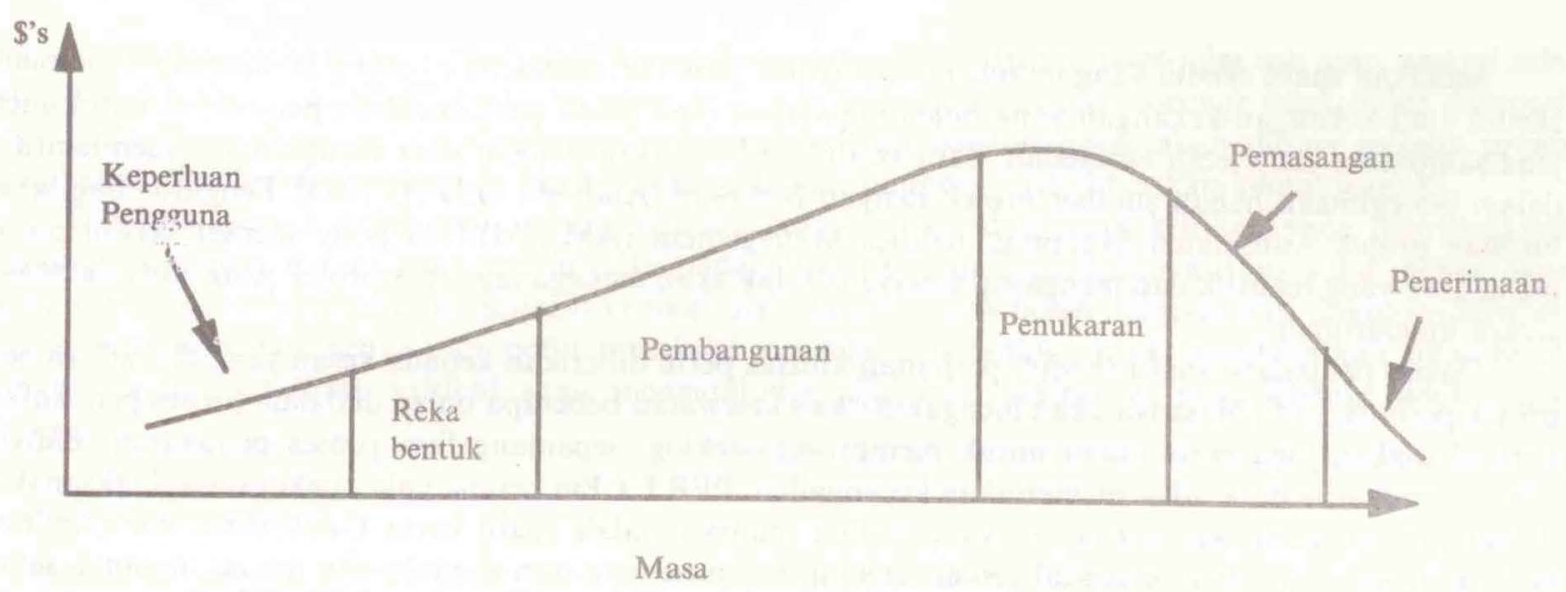

(a)

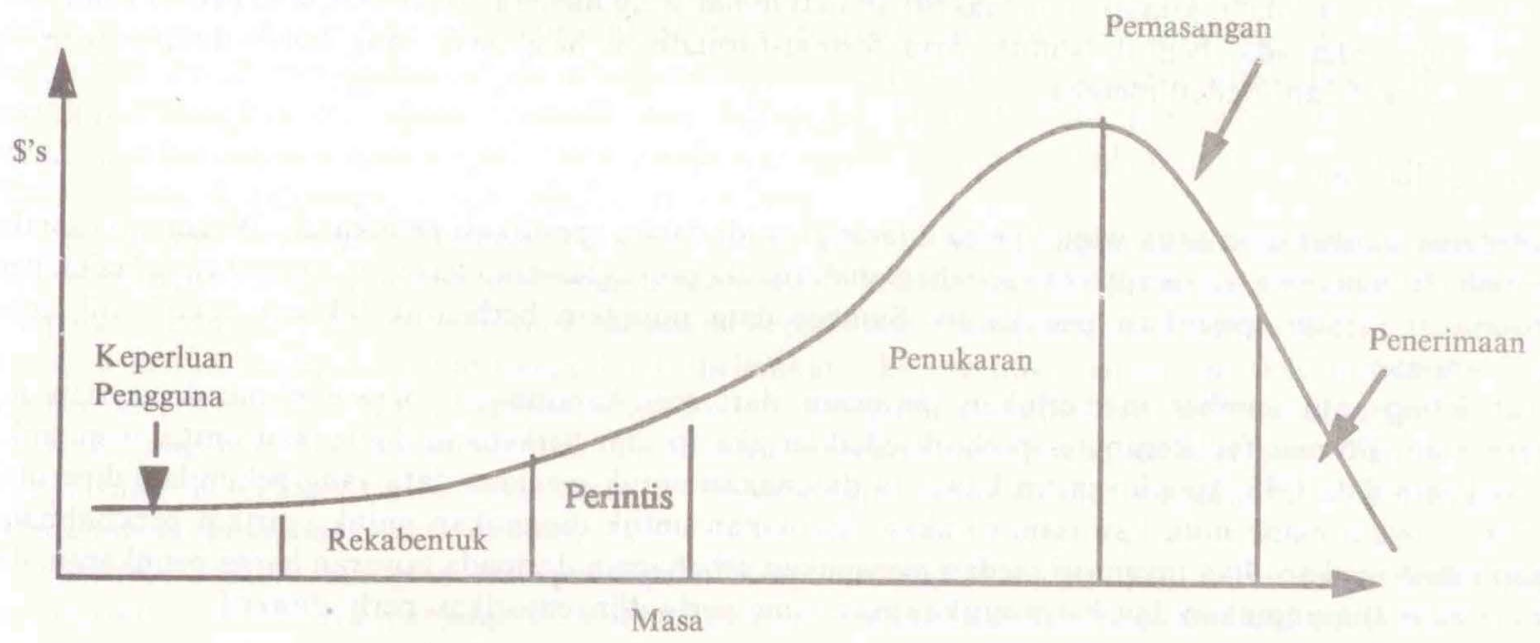

(b)

Gambarajah 3: Corak Perbelanjaan: (a) Sistem Maklumat Biasa lawan

(b) Sistem Maklumat Geografi (GIS)

(k.J.Lynis, Sharma, 1990)

\section{Skedul}

Skedul memberi kesan yang ketara dalam menentukan perbelanjaan suatu projek penukaran. Skedul yang terlalu lama ataupun yang melibatkan aktiviti penukaran tanpa penerusan akan mengakibatkan kos yang lebih tinggi. Walau bagaimanapun, skedul yang terlalu singkat pula adalah hasil daripada kekurangan pengalaman pihak penggunaan dalam salah faham tentang kerumitan tugas penukaran [Adrew, G.D.H, 1990]. Masa hanya merupakan salah satu kekangan yang perlu diuruskan. Kekangan-kekangan lain masih perlu dipertimbangkan. Dalam sebarang sistem GIS/Am/FM, kebanyakan daripada masa yang diperuntukkan adalah tertumpu kepada fasa penukaran data (Gambarajah 3). Keadaan ini tidak berlaku dalam sistem maklumat yang bukan melibatkan data ruang. 
Sediakan suatu skedul yang terancang dan seelok-eloknya, sediakan sebarang keutamaan-keutamaan skedul atau kekangan-kekangan yang boleh digunakan oleh pihak perkhidmatan penukaran untuk menjana sampukan yang lebih berfaedah. Satu skedul perlu ditakrif dengan jelas supaya dapat membantu di dalam penggunaan bahan sumber projek dengan berkesan [Andrews G.D.H, 1990]. Pengurus bagi keseluruhan projek Automated Mapping/facilities Management (AM/FM)/GIS perlu menset skedul proses penukaran yang realistik dan mengawal supaya ia tidak akan mengganggu fasa projek yang lain dan projek secara keseluruhan.

Dalam penjanaan suatu skedul, perhatian khusus perlu diberikan kepada kesan yang dihasilkan oleh projek perintis, yang biasanya akan mengakibatkan kelewatan beberapa bulan di dalam proses penukaran. Pertimbangkan juga permintaan untuk memproses'backlog' sepanjang fasa proses penukaran. Banyak projek penukaran data tidak memerlukan kecanggihan PERT/CPm kerana pakej-pakej kerja dilaksanakan dalam jujukan atau selari. Kaedah yang paling mahsyur ialah suatu carta Gantt/carta bar [Andrew, G.D.H, ,1990]. Setelah satu skedul sesuai ditemui, maka pengawasan skedul perlu dibuat biasanya setiap minggu adalah diwajibkan.

\section{Spesifikasi Data}

Dalam spesifikasi data, kita akan menakrifkan maklumat yang menerangkan sifat tabii proses penukaran: data yang sedia ada, bentuk-bentuk serta format-formatnya; hasil-hasil yang boleh disampaikan dan fomrat fizikal dan logikal mereka.

\section{Data Sedia-Ada}

Kesemua sumber data yang wujud perlu diterangkan di dalam spesifikasi penukaran. Walaupun semakan semula ke atas kawasan merupakan sebahagian daripada proses tawaran tersebut, sampel yang lazim, perlu disertakan dalam spesifikasi penukaran. Sumber data mungkin berbentuk lukisan. rekod fail, rekod terkomputer.

Setiap satu sumber memerlukan perincian dari segi kandungan, piawaian menderaf dan juga ketepatan. Format fail komputer perlu disediakan jika format berkenaan digunakan untuk memuatkan pangkalan data GIS. Jika inventori kawasan digunakan untuk menjana data yang belum lagi diperolehi, format dałam mana nota kawasannya akan disediakan untuk disediakan untuk syarikat perkhidmatan, perlu diperincikan. Jika inventori medan merupakan sebahagian daripada tawaran harga penukaran, data yang akan dikumpulkan dan kawasan-kawasan yang perlu diinventorikan perlu ditakrif.

\section{Hasil keluaran}

Di sini, takrifkan bolehsampaian yang dihasilkan oleh proses penukaran dan struktur data yang diperlukan oleh sistem GIS. Format fizikal output iaitu, media komputer dan formatnya (contoh 9 trk 6250 bpi tape magnetik) dan keperluan salinan keras (pelot-pelot, kad aperture, laporan pengkalan data, laporan suntingan, laporan jejakan) perlu ditentukan. Salinan keras sepenuh akan menambahkan kos penukaran dan kemungkinan bukan satu keperluan, sekurang-kurangnya sehingga proses penerimaan telah selesai. Kertas salinan keras boleh diganti dengan kad 'aperture'. Spesifikasi secara gerafik merupakan sebahagian daripada bahagian terbesar dokumen spesifikasi. Struktur data yang terlalu bergantung kepada sistem yang dituju, mengandungi takrifan logikal dan fizikul fail, peraturan penanaman fail komputer dan hasilhasil lukisan. Persimbolan grafik bagi setiap entiti (feature) dan data atribut yang dikaitkan dengannya secara grafik juga perlu ditakrifkan.

Piawaian-piawaian pemetaan, sistem unjuran dan koordinat, kandungan peta dan ketepatan perlu dikenalpasti jika dasar tanah merupakan sebahagian daripada spesifikasi penukaran. Piawaian menderaf bagi hasil terakhir perlu disediakan. Piawaian menderaf ini serupa dengan piawaian menderaf secara insani yang mempengaruhi penempatan setiap ciri grafik dengan sendiri dan mengaitkan dengan ciri-ciri lain dalam lukisan. Piawaian ini juga merangkumi piawaian untuk kegunaan rujukan penempatan 'bubble' untuk rujukan teks, peruangan kabel berhubungan dengan teks kabel, orientasi teks, penggunaan perincian pada lukisan yang sama ataupun yang berlainan.

Spesifikasi pengkalan data mesti menakrif struktur data yang bergantung kepada sistem 'host'. Entiti 
dan atribut dan perhubungan data perlu ditakrifkan. Bagi setiap atribut, julat-julat sah atau senarai nilai yang sah diperlu ditakrifkan. Nilai lalai yang akan digunakan jikalau nilai sebenar tidak boleh didapati, juga perlu ditakrifkan. Setiap atribut perlu dikenalpastikan bagaimana ia akan dibina melalui proses penukaran. Sumber data, ataupun jika terdapat pelbagai sumber, perlu diberikan keutamaannya.

Terdapat banyak kelas atribut yang berbeza-beza, kritikal dan tidak kritikal, yang menunjukkan pentingnya atribut dalam penggunaan data pada masa akan datang. Suatu atribut yang menentukan penyambungan rangkaian dikira sebagai kritikal. Jika data ini tidak boleh didapati dari dokumen sumber, agensi perkhidmatan penukaran perlu membuat penyelidikan lanjut untuk mendapatkan nilai betul, sebaliknya, atribut tidak kritikal akan mengandungi nilai lalai sekiranya, nilai sebenar tidak dapat diperolehi.

\section{Spesifikasi Pentadbiran}

Bahagian ini merangkumi isu pentadbiran berkaitan dengan sambutan kepada spesifikasi penukaran, sifat kontrak, pendekatan di dalam penentuan harga yang digunakan, dan perantaramuka yang akan ditetapkan dan diselenggarakan sepanjang proses penukaran. Spesifikasi tersebut perlu menentukan format sambutan dan tarikh tutup tawaran. Jika kajian semula dokumen sumber diperlukan, masa yang secukupnya perlu diberikan kepada setiap penawar untuk meneliti dokumen-dokumen tersebut. Pertanyaan-pertanyaan mungkin timbul semasa penyediaan tawaran-tawaran. Mekanisme yang digunakan untuk mengendalikan pernyataan-pernyataan tersebut juga perlu ditakrifkan. Harus ada sekurang-kurangnya hubungan teknikal dan hubungan kontrak atau pembelian untuk menjawab pertanyaan-pertanyaan sedemikian. Satu mesyuarat perlu dirancang dalam mana semua pertanyaan akan diterima dan dijawab di hadapan semua penawar.

Sekali lagi, masa yang cukup perlu diskedulkan sebelum dan selepas penawar, supaya pembekalpembekal dapat menghuraikan soalan-soalan dan meneliti semula jawapan-jawapan. Keperluan-keperluan ketepatan merupakan kepentingan yang bermakna kepada penerima-penerima tawaran. Ketepatan mutlak biasanya bukan merupakan suatu keperluan, melainkan jika inventory lapangan (field inventory) ialah sumber data. Ketepatan yang relatif terhadap dokumen-dokumen sumber dan penyelesaian bagi keadaankeadaan yang luar biasa ataupun data kritikal yang hilang merupakan ciri-ciri yang biasa. Kaedah menghitung ketepatan perlu dikenalpasti. Ia mungkin berdasarkan kepada ciri (feature) atau kebiasaannya, komponen suatu ciri-ciri.

Sebagai contoh, mungkin terdapat lapan komponen utama dalam penukaran suatu kabel iaitu penempatan bergrafiknya, panjangnya, saiz, tahun ditempatkan, kabel sumber dan kod perakaunan. Jika salah satu daripadanya disalahtukarkan maka ia merupakan suatu ralat. Suatu kabel yang tertinggal sama sekali bererti melibatkan berlakunya lapan ralat. Jumlah bilangan komponen yang disampaikan boleh didapati daripada pengkalan data. Kaedah untuk mengenalpasti ralat dan menentur $n$ n tahap ketepatan perlu ditentukan dalam spesifikasi. Semakan-semakan biasanya mengandungi semakan aturcara pada atribut pengkalan data untuk memastinan kebolehjejakan nilai dan rangkaian yang betul.

Suatu semakan insani untuk suatu bahagian grafik terpilih perlu dibuat sebagai tambahan, kebiasaannya sebanyak $5-10 \%$ tetapi kadangkala $100 \%$ bagi hasil yang pertama dari syarikat fasiliti. Kaedah untuk menentukan harga mesti dikenalpasti, iaiţu masa dan bahan, harga setiap unit bagi item hasilan yang telah dikenalpasti atau jumlah campuran sesuatu tugas. Berbagai pilihan pembilang atau pembayaran boleh didapati. Kebiasaannya ialah kemajuan pembilan atau pembayaran bulanan yang tersekat, tetapi ada kontrak yang mengkehendaki pembilan 'milestone' projek ataupun pembayaran setelah penerimaan hasil atau selesai. Akhir sekali, spesifikasi pentadbiran perlu menakrif status keperluan pelapuran. Kebiasaannya agensi perkhidmatan pernukaran akan mempunyai kawalan ketat terhadap projek namun demikian ini boleh diuruskan melalui pembayaran bulanan atau lebih kerap lagi jiká diperlukan oleh pelanggan.

\section{PERTIMBANGAN PRA-PENUKARAN}

Walau bagaimanapun setelah pelaksanaan spesifikasi ini selesai, penukaran data tidak boleh dilaksanakan serta merta sehingga satu dasar yang tepat, terkini dan selaras dengan tempat data fasiliti dirujuk secara geografik dipertimbangkan. Begitu juga dengan mutu data yang akan ditukar, di mana penyediaan dan 
pembersihan data tersebut perlu juga diberi perhatian.

\section{PENUKARAN}

Proses ini melibatkan penukaran maklumat yang terkandung dalam dokumen sumber kertas kepada pangkalan data digital yang mewakili peta-peta atau lukisan-lukisan. Sebagai tambahan, penterjemahpenterjemah di antara sistem-sistem GIS yang popular perlu ditulis untuk mengintegrasikan data dari pangkalan data yang sedia dengan pangkalan data GIS yang akan dibina [Frank, G 1990], [Carl, N.R, 1990]. Untuk menentukan kejayaan bagi setiap projek AM/FM, satu falsafah penukaran perlu diikuti. Satu komponen kritikal dalam falsafah tersebut adalah penyertaan pihak yang terlibat dengan penukaran di dalam dua aktiviti kritikal pada tahap awal projek GIS. Aktiviti tersebut dapat diterangkan seperti di bawah:

1. Menganalisa keadaan pra-penukaran sesuatu organisasi iaitu dalam bentuk data yang sedia ada, aliran maklumat yang sedia-ada, keperluan pengguna dan sebagainya.

2. Memahami dan menghayati objektif projek organisasi tersebut dan hanya lebih penting sekali, penggunaan yang dijangkaan daripada pangkalan data yang akan dibina.

Pemahaman sepenuhnya mengenai kedua-dua aktiviti ini merupakan satu tanggungjawab ikhtisas [Bill, $\mathrm{K}$ 1980]. Melalui pemahaman tersebut, pihak yang terlibat dalam proses penukaran akan dapat menyesuaikan proses penukaran bagi organisasi tertentu dan dengan ini membolehkan organisasi tersebut menghasilkan suatu penyelesaian penukaran yang terbaik sama ada secara teknikal atau ekonomi. Syarikat swasta penukaran yang pernah terlibat dalam projek AM/FM atau GIS telah membuktikan satu kenyataan bahawa tidak terdapat satu kaedah khusus yang boleh menjayakan semua projek.

Setiap projek adalah berbeza-beza dan setiap organisasi objektif projek mereka yang unik iaitu spesifikasi teknikal mereka yang unik, rekod sedia ada dan set data digital mereka yang unik. Biasanya, perbezaan-perbezaan ini wujud bukan sahaja antara syarikat-syarikat atau agensi-agensi tetapi juga daerah-daerah dalam syarikat yang sama.

Walaupun terdapat banyak tugas yang terangkum satu proses penukaran, takrifan mudah bagi istilah 'proses' mungkin boleh dijadikan satu titik permulaan yang baik. Apabila penukaran GIS atau AM/FM dikaji sebagai satu 'proses' ia boleh dirumuskan kepada empat komponen:

1. Sumber Maklumat - Apakah input kepada proses tersebut.

2. Teknologi - Apakah 'alat' yang akan digunakan untuk melaksanakan proses ini.

3. Metodologi - Bagaimanakah teknologi digunakan untuk melaksanakan proses ini.

4. Kecanggihan hasil akhir - Berapa banyak yang diharapkan daripada output proses ini.

Disebabkan darjah penyesuaian projek yang diperlukan seperti yang dibincangkan pada bahagian awal, maka tidak terdapat satu projek yang lazim (typical). Walau bagaimanapun, sebagai satu rangka rujukan, Gambarajah 4 menerangkan aliran kerja penukaran yang berkaitan dengan satu projek AM/FM atau GIS yang lazim (typical).

\section{Keperluan Kepada Dasar Tanah Digital}

Kebanyakan projek melibatkan pembinaan atau perolehan satu dasar tanah digital baru dan tepat keseluruhannya. Kebanyakan syarikat swasta yang bercadang untuk memulakan penukaran kepada suatu persekitaran GIS (AM/FM) mendapati bahawa, jika mereka masih belum menyedarinya, sistem pemetaan kini menunjukkan ketepatan-ketepatan berkedudukan yang tidak tetap. Kadangkala sistem ini dalam bentuk tabiinya, adalah skematik. Tambahan pula, sistem pemetaan yang diselenggarakan secara insani lazimnya berdasarkan kepada sistem grid bukan piawai atau sistem grid sembarangan. Objektif perolehan dasar tanah tersebut adalah untuk mengasaskan bahagian pengurusan pangkalan data kepada dasar tanah. yang kemaskini dan tepat secara seragam. Lazimnya, kaedah fotogrammetri dapat membentuk asas bagi dasar tanah baru tersebut. Teknologi yang digunakan untuk memperolehi dasar tanah ini banyak didapati seperti fotogrammetri, imbasan raster, pendigit stereo, ortofotografi dan sebagainya dan sebagainya [Bill K., 1989]. 

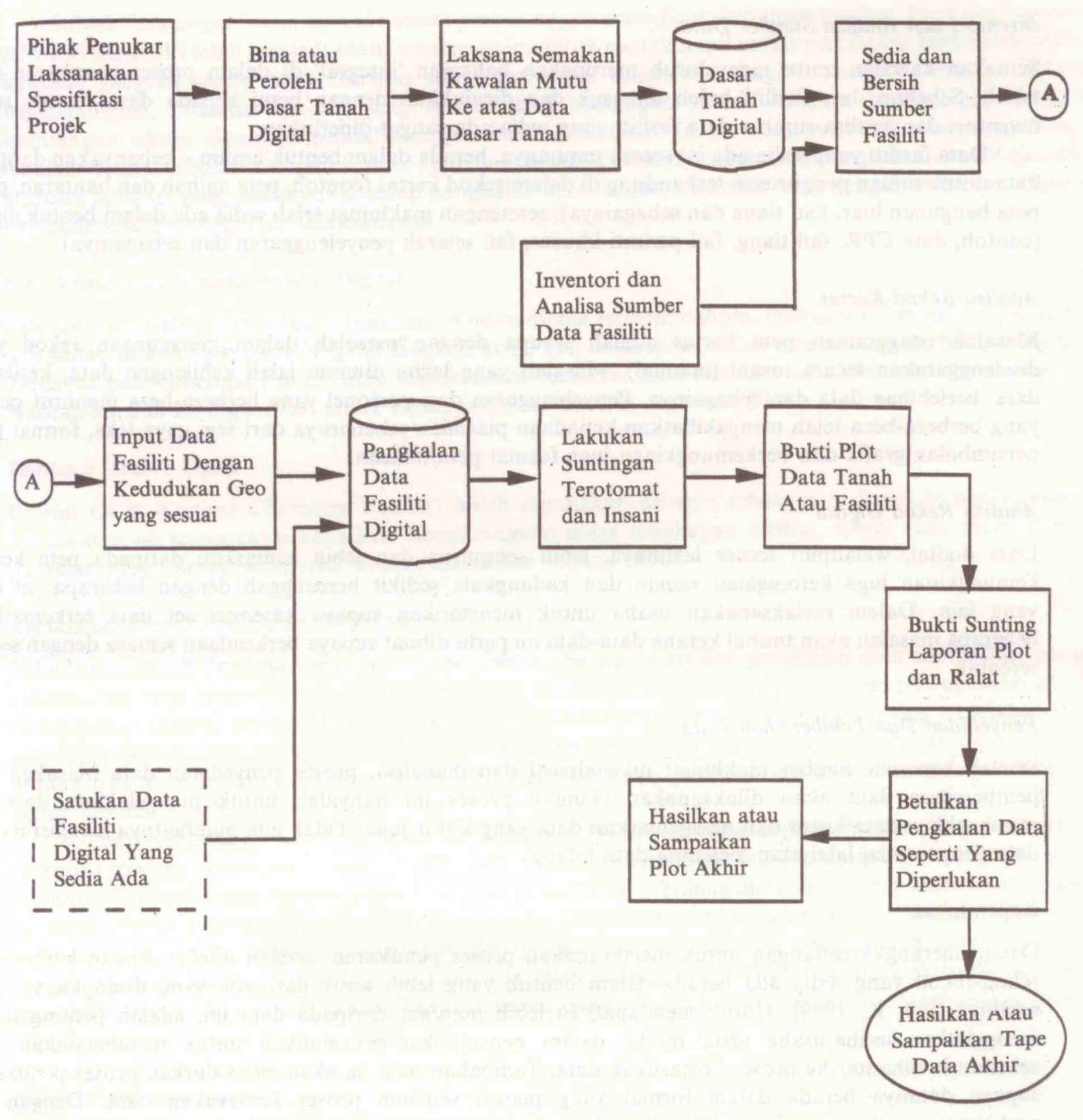

Gambarajah 4: Aliran Kerja Penukaran Lazim 


\section{Inventori dan Analisa Sumber Data}

Semakan kawalan mutu menyeluruh merupakan bahagian 'integral' di dalam proses penukaran data tanah. Sebelum data fasiliti boleh dimasuk dan dirujukkan dengan betul kepada dasar tanah, suatu inventori dan analisa sumber data fasiliti yang sedia ada sangat diperlukan.

Data fasiliti yang sedia ada ini secara umumnya, berada dalam bentuk umum - kebanyakan daripada data untuk tujuan pengurusan terkandung di dalam rekod kertas (contoh, peta agihan dan hantaran, petapeta bangunan luar, kad tiang dan sebagainya); sesetengah maklumat telah sedia ada dalam bentuk digital (contoh, data CPR, fail tiang, fail peranti-khusus, fail sejarah penyelenggaran dan sebagainya).

\section{Analisa Rekod Kertas}

Masalah penggunaan peta kertas adalah serupa dengan masalah dalam penggunaan rekod yang diselenggarakan secara insani (manual). Masalah yang lazim ditemui ialah kehilangan data, kesilapan data, berlebihan data dan sebagainya. Penyelenggaran dari personel yang berbeza-beza menurut piawai yang berbeza-beza telah mengakibatkan ketiadaan piawaian sebenarnya dari segi gaya teks, format teks, persimbolan grafik dan berkemungkinan juga format peta/lukisan.

\section{Analisa Rekod Digital}

Data digital, walaupun secara lazimnya, lebih sempurna dan lebih kemaskini daripada peta kertas, kemungkinan juga ketinggalan zaman dan kadangkala sedikit bercanggah dengan beberapa set data yang lain. Dalam melaksanakan usaha untuk menetapkan supaya kesemua set data terkemaskini, beberapa masalah akan timbul kerana data-data ini perlu dibuat supaya berkeadaan semasa dengan secara serentak.

\section{Penyediaan Dan Pembersihan Data}

Setelah kesemua sumber maklumat dikenalpasti dan dianalisa, proses penyediaan data masukan dan pembersihan data akan dilaksanakan. Tujuan proses ini hanyalah untuk mengelakkan daripada memasukkan data kotor dan mengeluarkan data yang kotor juga. Tidak ada manfaatnya mengisi medan data dengan nilai lalai atau 'penanda data hilang'.

\section{Kepentingan}

Dalam merangka cadangan untuk melaksanakan proses penukaran, setelah diteliti dengan lebih halus, rekod-rekod yang sedia ada berada dalam bentuk yang lebih teruk daripada yang disangkakan pada awalnya [Bill, K, 1989]. Untuk mendapatkan lebih manfaat daripada data ini, adalah penting untuk menggiatkan usaha-usaha serta modal dalam penyelidikan-penyelidikan untuk membersihkan data sebelum ia dihantar ke proses kemasukan data. Tambahan pula, ia akan menyalurkan proses penukaran supaya datanya berada dalam format yang piawai sebelum proses kemasukan data. Dengan ini, perbelanjaan pelanggan dapat dijimatkan dalam jangka masa panjang kerana data data telah pun berada dalam format yang ditentukan dan tidak dalam format selain daripada piawai. Penggunaan data yang tepat dan pelaksanaan sistem yang unggul amat diperlukan untuk mencapai matlamat tersebut. Seorang vendor penukaran tidak akan mempunyai kawalan terhadap sistem tetapi boleh mengawal ketepatan data. Di dalam penyediaan dan pembersihan data untuk proses penukaran, amaun tafsiran maklumat litar yang ketara, piawaian grafik dan penformatan semula teks mungkin diperlukan.

Tahap usaha proses penukaran tersebut, sekali lagi, bergantung kepada spesifikasi-spesifikasi projek dan jangkaan-jangkaan. Suatu rumusan, hasil daripada beberapa kes, telah dibuat bahawa suatu inventori medan yang lengkap, sebelum daripada proses penukaran, adalah jauh lebih murah perbelanjaan berbanding dengan memasukkan terus rekod sedia ada dan kemudian menghadapi masalah data yang berlebihan, hilang dan mempunyai ralat. Dalam kes yang lain, verifikasi medan separa sudah memadai. Walau bagaimanapun pada peringkat penyediaan data, pihak-pihak lain bergantung kepada kemampuan agensi perkhidmatan penukaran untuk menjalankan penyelidikan pelbagai sumber dan menggunakan teknik-teknik sokongan sumber tambahan. 
Subjek 'bentangan' akan timbul semasa perbincangan persediaan dokumen sumber. Pada awal zaman AM/FM atau GIS telah menjadi suatu amalan lazim untuk mengkompil maklumat fasiliti berkenaan suatu kawasan geografi secara insani ke atas suatu plot dasar tanah baru bagi kawasan berkenaan. Walau bagaimanapun, bilangan kes-kes yang memerlukan bentangan penuh semakin berkurangan dengan kedatangan teknik algoritma pendaftaran/penskelan dokumen. Tanpa mengira teknik yang digunakan, manfaat yang diperolehi menjadi ketara, apabila pelanggan mula menggunakan pangkalan data. Kejayaan aturcara aplikasi yang dilarikan terhadap pangkalan data, adalah berkadar terus dengan usaha persediaan dan pembersihan yang telah dilaksanakan.

\subsection{Penukaran Kepada Bentuk Digital}

Sebelum pangkalan data boleh digunakan, ia perlu dibina terlebih dahulu. Dokumen sumber yang tersedia dan sudah dibersihkan pada langkah-langkah awal, kini telah sedia untuk ditukar kepada bentuk digital. Terdapat pula beberapa kaedah atau teknik untuk menukar data fasiliti tersebut kepada bentuk digital. Kaedah-kaedah ini digunakan untuk kebanyakan sistem GIS atau AM/FM.

\section{Pembaca Aksara Optik}

Peranti OCR (Optical Character Reader) boleh digunakan sebagai sebahagian daripada penyelesaian. Pendekatan ini mempunyai kebaikan mengurangkan masa tangkapan atribut, tetapi akan memerlukan piawaian yang hampir sempurna semasa masukkan borang input.

\section{Kemasukan Data Luar-Talian (Off-Line)}

Teknik yang telah diterima umum dalam pembinaan bahagian atribut pangkalan data melibatkan penggunaan, apa yang lazim disebut sebagai kemasukan data luar-talian. Jurutaip yang cekap ditugaskan untuk memasukkan atribut-atribut. Bagi projek yang memerlukan ketepatan kuantitatif yang melebihi $95 \%$, agensi penukaran akan menggunakan kaedah masa - terbukti iaitu dengan cara menentukan supaya setiap borang teks atau dokumen sumber ditaip berasingan oleh dua jurutaip dan kemudian membandingkan kedua-dua fail tersebut.

Konsep kemasukan teks luar-talian khususnya lebih ditumpukan kepada projek yang melibatkan inventori medan. Dalam hal demikian, data teks secara umumnya berasingan daripada data grafik pada mulanya. Perkembangan teknologi telah memberi kesan ke atas bidang ini. Data atribut boleh dimasukkan ke dalam medan pada masa permulaan data, melalui peranti tangkapan data pegangan tangan. Versi-versi unit yang lebih maju boleh diaturcarakan dan dengan ini memudahkan penyemakan nilai julat teks. Setelah selesai ataupun apabila ingatan yang ada telah penuh, data dihantar secara elektronik daripada peranti ke sistem GIS yang digunakan untuk menjana pangkalan data, dan dengan ini menghasilkan model digital rangkaian fasiliti yang menyeluruh.

\section{Sistem Pengecam suara}

Sistem pengecaman suara yang digunakan dalam proses penukaran masih berada dalam peringkat pembangunan. Langkah-langkah pesat di dalam memperbaiki sistem-sistem tersebut. Versi-versi sistem ini yang termaju, memperolehi kebolehlenturan yang diperlukan untuk membolehkan pengguna menggunakan senarai-senarai kod dan singkatan fonetik (bunyi bahasa). Sesetengah agensi penukaran telah membangunkan kaedah untuk mengoptimakan pengaktifan perintah-perintah dan pengecaman nama medan data melalui penggunaan sistem pengecaman suara. Pembaikan lain yang perlu diberi perhatian ialah penambahan perpustakaan perkataan perintah.

\section{Imbasan}

Imbasan, yang kadangkala disebut sebagai pendigitan otomatik, merupakan sebahagian daripada pengurusan fasiliti dalam proses penukaran. Kualiti yang buruk dan kekurangan pempiawaian yang mencirikan majoriti daripada rekod/peta hantaran dan agihan dan peta/rekod bangunan luaran, telah menghalang agensi penukaran daripada menggunakan teknologi berkenaan melalui proses penukaran satu 


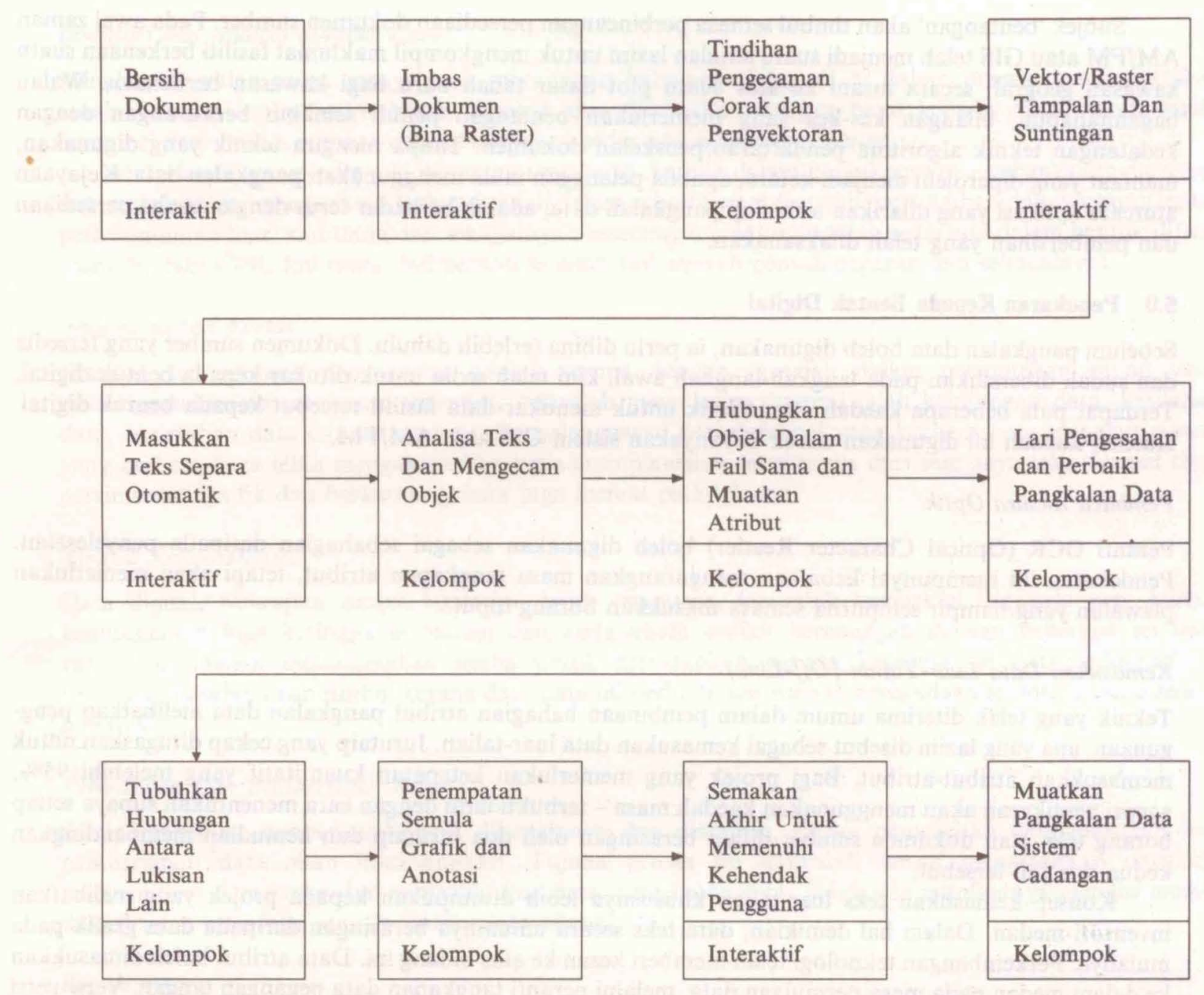

menunjukkan proses sistem pakar

Gambarajah 5: Rajah Aliran Proses Penukaran Menggunakan Teknologi Baru 
langkah. Sifat semulajadi dokumen sumber input, menghalang mereka daripada menginput dokumen kepada pengimbas dan menghasilkan serta merta pangkalan data yang tepat, terskel dan ditempatkan dengan tepat dan pintar sepenuhnya.

\section{Keperluan Kepada Imbasan}

Walau bagaimanapun, jika keperluan bukan untuk menghasilkan pangkalan data pintar, iaitu jika keperluan, sebagai contoh, hanya untuk menghasilkan imej bergambar rekod yang sedia ada, maka pengimbasan adalah penyelesaiannya. Pengimbas boleh digunakan terus untuk melaksanakan tugas membina pangkalan data jenis archival, yang mengandungi fail raster yang sebenarnya merupakan fotograf digital dokumendokumen asal. Kemungkinan kemusykilan akan timbul jika kaedah satu langkah ini digunakan ialah-

1. Bolehkah laporan dijana daripada pangkalan data raster ini? - tidak.

2. Bolehkan applikasi kejuruteraan dilarikan terhadap pangkalan data raster ini? - tidak.

Imbasan adalah penyelesaiannya jika pelanggan ingin mencari jalan untuk menamatkan satu keadaan di mana rekod akan menjadi bertambah buruk dan ia juga merupakan satu persembahan sistem pengurusan terkomputer bagi imej grafik yang sertakan dalam sistem rekod-rekod mereka. Pangkalan data raster ini, pada suatu masa nanti, boleh dikembangkan kepada satu pangkalan data vektor pintar. Ini boleh dilaksanakan melalui kombinasi proses-proses otomatik (iaitu penukaran raster kepada vektor, pengecaman simbol) dan penyuntingan pangkalan data vektor oleh pengendali pada stesyen kerja grafik [Karen, I, 1990]. Proses tersebut dapat dilihat pada Gambarajah 5. Pendekatan ini, sesuai bagi pelanggan yang skedul projek dan objektifnya membolehkan pembayaran kos penukaran dibuat secara berperingkat [Charles, D.H. ,1990]. Kebanyakan daripada pelanggan mampu untuk membayar kos bagi tambahan kepintaran pangkalan data dan applikasi-applikasi yang berkaitan.

\section{Hybrid}

Pendekatan 'hybrid' merupakan satu kemungkinan dalam bidang data fasiliti. Adalah lebih baiknya untuk mendigit data vektor pintar di atas data latarbelakang raster yang dungu. Data latarbelakang ini boleh jadi sama ada dasar tanah atau imej sumber dokumen fasiliti yang sedia ada [Skashita.S, Yutaka.T,1990]. Walau bagaimanapun, kaedah ini akan mengakibatkan masa pembayaran balik yang agak lama tetapi merupakan kaedah yang dapat mengurangkan kos [Bill,K,1989] kerana masa yang diambil untuk melaksanakan proses pendigitan boleh disingkatkan.

\section{TAHAP KECANGGIHAN}

Seperti yang disebutkan sebelum ini, keseluruhan idea dalam melaksanakan sebarang proses ialah untuk mendapatkan hasil. Dalam kes proses penukaran AM/FM, hasil yang diingini ialah satu set maklumat yang berorientasi geografi yang telah diperbaiki fasiliti pelanggan yang telah dipasang dan dirancangkan. Tahap kecanggihan yang dimiliki oleh hasil akhir ternyata sekali disebabkan oleh pilihan yang dibuat dalam bidang-bidang yang telah dibincangkan terdahulu iaitu, perolehan dasar tanah, persediaam sumber, pembersihan data, kaedah kemasukan data dan applikasi yang dicadangkan dan sebagainya. Walau bagaimanapun faktor tambahan akan menyerap pada setiap langkah-langkah yang terlibat di dalam proses penukaran, yang secara langsung akan menentukan kebolehgunaan hasil akhir iaitu pangkalan data digital. Faktor tersebut ialah kawalan mutu. Tanpa pengukuran kawalan mutu, pelanggan berkemungkinan besar akan menerima data yang bermutu rendah, dan dengan ini menimbulkan ketidakpuasan.

\section{KAWALAN MUTU}

Salah satu faktor yang memberi kesan terhadap kos penukaran data ialah mutu maklumat [Henry, A.M, 1989]. Faktor ini memberi kesan dengan dua cara. Pertama tahap mutu bahan sumber yang dipertimbangkan kerana ia akan menentukan amaun penyediaan dan pembetulan data yang diperlukan. Kedua ialah tahap mutu bagi hasil keluaran. Matlamat kawalan mutu adalah untuk menyediakan maklumat bolehguna untuk tujuan menganalisa pangkalan data, iaitu pengkalan maklumat yang $100 \%$ 
betul [Monica, S.D, 1990] dan salah satu daripada cara untuk mengawal mutu maklumat ialah proses penyuntingan.

Penyuntingan projek tertentu biasanya dilaksanakan secara habis-habisan oleh biro perkhidmatan penukaran yang berpengalaman. Kombinasi suntingan torotomat dan insani digunakan untuk menyemak data sebaik sahaja ia telah digit. Penyuntingan terotomat akan memeriksa kesahan medan teks dalam pangkalan data, hubungan pangkalan data, kaitan grafik dan logik.

\section{Suntingan Aktif}

Suatu contoh aturcara suntingan aktif ialah satu aturcara batch 'snap' yang menyesuaikan kedudukan koordinat untuk memastikan berkebetulan antara dua entiti tertentu. Aturcara seperti ini, membaca daripada pangkalan data dan menulis ke pangkalan data (untuk mencatit penyesuaian kordinat), dan proses ini dilabelkan sebagai aktif.

Lebih-lebih lagi, aturcara suntingan aktif secara umumnya akan mengeluarkan pesanan ralat yang berkaitan dengan masa, ketika mana ia tidak dapat mencapai tindakan yang sepatutnya. (Contoh melaporkan satu entiti yang sepatutnya di 'snap' tetapi tidak berjaya).

\section{Suntingan Pasif}

Suntingan yang pasif tidak melaksanakan penyediaan data tetapi hanya melaporkan data yang beralat. Suatu contoh ialah satu aturcara yang mengesan satu patahan dalam penyambungan litar dan melaporkan lokasi patahan dan jenis/jenis-jenis entiti komponen-komponen litar yang terlibat. Biasanya, pembangunan suntingan-suntingan ini berdasarkan kepada modul sunting data asal yang disediakan oleh pembekal (vendor) sistem tersebut. Biro perkhidmatan penukaran biasanya bekerjasama dengan pelanggan untuk mengubahsuaikan (customize) penyuntingan untuk memasukkan modul yang boleh menghasilkan senarai kod projek-khusus, julat nilai yang sah, kriteria suntingan perhubungan dan sebagainya.

\section{Suntingan Insani}

Suntingan insani kebiasaannya adalah suntingan berdasarkan penglihatan. Suntingan jenis ini dimudahkan oleh 'plot bukti' bagi maklumat fasiliti dan tanah yang berkaitan dengan satu kawasan geografi tertentu dan laporan ralat yang dijana oleh suntingan terotomat yang diterangkan sebelum ini. Dalam banyak kes, satu perbandingan sebelah menyebelah dijalankan antara plot bukti dan dokumen asal. Pegawai kawalan mutu yang menjalankan kajian semula akan membuat catatan untuk menjelaskan plot bukti dengan menggunakan arahan-arahan pembetulan.

Plot yang tersunting kemudian dihantar semula ke bahagian kemasukan data untuk pembetulan. Sebaik sahaja, data mencapai kepada mutu yang boleh diterima dan disampaikan, plot akhir dihasilkan. Plot akhir adalah tertakluk kepada kajian semula mutu yang bersifat estetik dan setelah kesemua plot dalam kumpulan yang boleh disampaikan boleh diterima, maka data akan disalin ke dalam masa media akhir - biasanya tape magnetik. 'State-of-the-art' pangkalan data GIS berkemampuan untuk menyokong satu julat luas applikasi yang memerlukan berbagai peringkat sistem dan kecanggihan struktur data yang boleh dikategorikan kepada 4 bahagian asas:-

1. Output Grafik

2. Lapuran

3. Perantaramuka

4. Analisa/Pemodelan

\section{OUTPUT GRAFIK}

Berbagai jenis output yang boleh didapati daripada sistem AM/FM buat masa ini.

Ramai pelanggan pada mulanya, menggunakan sistem mereka untuk menghasilkan lukisan/peta-peta piawai yang direkabentuk semasa takrifan projek. Walau bagaimanapun, sebaik sahaja sistem tersebut dan pangkalan data dipasang, mereka telah dapat menjana peta-peta khusus dan lukisan-lukisan dengan senang dan pantas. 
Sistem GIS atau AM/FM membolehkan penghasilan peta-peta pada skel yang ditentukan oleh pengguna dan memaparkan ciri-ciri (features) yang ditentukan oleh pengguna. Walaupun perolehan jenis applikasi output grafik ini merupakan yang paling murah, namum demikian tidak mudah untuk mewajarkan kos sebagai objektif unggul suatu projek AM/FM. Biro perkhidmatan penukaran yang canggih dan pengalaman akan mengetahui sendiri bahawa output yang diperolehi daripada pangkalan data hanyalah hasil sampingan proses penukaran dan patut dianggap sebagai manfaat sampingan.

\section{Laporan}

Applikasi pelaporan juga tidak terbatas dan ini boleh termasuk laporan jenis-CPR, sejarah kegagalan, bilbahan, tertib kerja, kelas bangunan mengikut ketinggian mutu dan sebagainya. Manfaat yang boleh diperolehi daripada laporan-laporan ini secara langsung bergantung kepada kebolehlenturan pelaporan yang terdapat melalui perisian sistem dan keuntuhan data yang disediakan oleh biro perkhidmatan penukaran.

Fail-fail digital yang sedia ada kini menjadi satu ciri penting bagi pangkalan data AM/FM dan juga sistem penyelenggaraan yang terpilih. Pada awal-awal tahun AM/FM, pangkalan data diselanggarakan dalam persekitaran yang berasingan daripada pangkalan data perakaunan, maklumat inventori stor-stor, dan set data kritikal yang lain. Lambangniaga suatu sistem pengurusan fasiliti model ialah kemampuannya untuk menggunakan data dari dan hantar data ke pangkalan yang sedia ada. Kedua-dua consultant AM/ FM yang berpengalaman dan biro perkhidmatan penukaran sedar bahawa terdapat banýak manfaat ekonomi untuk menggabungkan data sedia wujud seperti fail-fail tiang, fail-fail injap atau fail pengurusan beban alatubah pada bila-bila masa yang mungkin.

\section{Pemodelan / Analisa}

Applikasi pemodelan/analisa membolehkan jurutera-jurutera dan perekabentuk-perekabentuk melaksanakan applikasi berdasarkan penghubungan seperti jejakan litar, pengimbangan fasa, perletakan peranti, pembaikan gelung, buangan kabel dan sebagainya. Asas bagi applikasi tersebut sebaik-baiknya mengandungi maklumat fasiliti pada suatu kedudukan (contoh satu alatubah pada litar utama), bagaimana fasiliti dihubungkan dan/atau diatur dan status fasiliti tertentu (contoh, satu kedudukan suis yang secara normal tertutup ataupun terbuka). Biro perkhidmatan penukaran yang berpengetahuan sedar akan perbezaan ketara dalam kerumitan berbagai jenis model rangkaian. Model pempaipan seperti air, saliran dan gas secara lazim merupakan model yang termudah untuk direkabentuk dan dilaksanakan.

Secara umumnya, mereka mengandungi bilangan peranti yang paling sedikit, ciri aliran yang paling mudah diramal dan konsisten dan kemungkinan pensuisan yang rumit bagi berbagai rangkaian fasiliti yang dipetakan.

\section{KESIMPULAN}

Setelah kesemua spesifikasi-spesifikasi telah dikenalpasti dan dilaksanakan dengan jayanya maka penukaran yang sebenarnya bolehlah bermula. Fasa penukaran data dalam sebarang projek GIS /AM/ FM merupakan usaha bersama antara pengguna dan syarikat yang memberikan perkhidmatan penukaran. Berjaya atau sebaliknya fasa ini merupakan faktor yang kritikal bagi kedua belah pihak. Proses penukaran secara rasminya 'berakhir' apabila keempat jenis applikasi (output grafik, laporan, perantaramuka, analisa) digunakan dengan jayanya oleh pengguna. Penyelenggaraan pangkalan data adalah terlalu rumit untuk dibincangkan buat masa ini.

Daripada kertaskerja ini kita dapat melihat gambaran umum mengenai apa yang dimaksudkan daripada proses penukaran dalam konteks GIS (Geographical Information System). Kajian terperinci belum lagi dilaksanakan kerana ini hanya merupakan kajian literatur tetapi telah cukup memberi gambaran pengetahuan tentang kepentingan proses tersebut. Kemungkinan besar langkah-langkah serta isi kandungan yang terdapat dalam kertaskerja ini dapat dijadikan rujukan dan garispanduan di dalạm mengelolakan sistem maklumat bagi data-data ruang (spatial). 


\section{RUJUKAN}

1. Andrews, G.D H - Adherence To Conversion Schedule: Crucial To Project Success, Proceedings Of AM/FM International XIII, 1990.

2. Bill, $\mathrm{K}$ - The Conversion Process - Proceedings AM/FM International 10.2, 1989.

3. Blunt, R.A., - Developing A Conversion Specification, Proceedings Of AM/FM International at 8th Annual Worldwide Utility Symposium, 1989.

4. Carl, N.R - Using CAD DATA In A GIS - Proceedings AM/FM Conference XIII, 1990.

5. Charles, H.D., Incremental Conversion - Impacting The Bottom Line. Proceedings AM/FM Conference XIII, 1990.

6. Emery, H.A., - Estimating Conversion Costs, AM/FM International, 8th Annual Worldwide Utility Symposium, 1989.

7. Franek. G - Translating Intelligent Graphics - Proceedings AM/FM Conference XIII, 1990.

8. Henry, A.M., - Estimating Conversion Costs - Proceedings Am/FM International 10.3, 1989.

9. Humphries, B, - The Crisis In Land Management - National Seminar On Land Information System, K.L., 1984.

10. Karen, I. - AM/FM Conversion Costs And Effect OF Recent Technologies Advances - Proceedings AM/FM Conference XIII, 1990.

11. Loxton, J, - Practical Map Productions, John Wiley And Sons, 1980.

12 .Lyons, K.J \& Sharma, - Lecture notes - Short course On LIS/GIS - ITM, Shah Alam, 1990.

13. Monica, S.D - Cartographic Quality Control - Proceedings AM/FM Conference XIII, 1990.

14. Sakashita S., T. Yutaka, - Computer Aided Drawing Conversion (An Interactive Approach To Digitise Map), Proceedings AM/FM Conference XIII, 1990. 